TECHNO

Vol.21, No.1, April 2020, Hal. 37 46

P-ISSN: 1410-8607, E-ISSN: 2579-9096

\title{
PENGARUH PENGGUNAAN FILLER PASIR BESI DAN SEMEN DALAM CAMPURAN ASPHALT CONCRETE WEARING COURSE $(A C-W C)$
}

\author{
Hery Awan Susanto \\ Jurusan Teknik Sipil \\ Fakultas Teknik, Universitas Jenderal Soedirman
}

\begin{tabular}{|c|c|}
\hline Informasi Makalah & INTISARI \\
\hline $\begin{array}{l}\text { Dikirim, } 21 \text { April } 2020 \\
\text { Direvisi, } 23 \text { April } 2020 \\
\text { Diterima, } 27 \text { April } 2020\end{array}$ & $\begin{array}{l}\text { Lapis aspal beton (laston) merupakan suatu lapisan perkerasan jalan yang } \\
\text { terdiri dari campuran aspal dan agregat yang mempunyai gradasi menerus } \\
\text { dicampur, dihampar dan dipadatkan pada suhu tertentu. Campuran asphalt } \\
\text { concrete wearing course (AC-WC) adalah salah satu jenis laston yang } \\
\text { berfungsi sebagai lapisan aus dan menahan tegangan akibat beban lalu lintas. }\end{array}$ \\
\hline $\begin{array}{l}\text { Kata Kunci: } \\
\text { Filler } \\
\text { Semen } \\
\text { Pasir Besi } \\
\text { Pengujian Marshall } \\
\text { AC-WC }\end{array}$ & $\begin{array}{l}\text { awet, permukaanya rata dan mampu memberikan gesekan yang baik dengan } \\
\text { roda kendaraan. Disisi lain, perubahan iklim dan beban lalu lintas kendaraan } \\
\text { yang semakin tinggi akan berdampak terhadap kinerja campuran AC-WC. } \\
\text { Penggunaan alternatif bahan pengisi (filler) dalam laston berperan penting } \\
\text { untuk meningkatkan kinerja campuran AC-WC. Pasir besi dan semen } \\
\text { memiliki tekstur yang kasar dan keras dibandingkan dengan abu batu } \\
\text { diharapkan mampu meningkatkan kinerja campuran AC-WC. Oleh karena itu } \\
\text { dalam peneltian ini semen dan pasir besi akan digunakan sebagai alternatif } \\
\text { filler campuran AC-WC. Pengujian Marshall dilakukan untuk melihat kinerja } \\
\text { campuran AC-WC dengan kombinasi filler 100\% pasir besi, 50\% pasir } \\
\text { besi+50\% semen, dan } 100 \% \text { semen dalam keadaan kering dan terendam air. } \\
\text { Hasil pengujian menunjukkan bahwa pasir besi dapat digunakan sebagai } \\
\text { filler dalam campuran AC-WC. Stabilitas tertinggi diperoleh dalam } \\
\text { campuran AC-WC dengan filler semen dan stabilitas terendah dari filler 50\% } \\
\text { pasir besi+50\% semen. }\end{array}$ \\
\hline
\end{tabular}

\section{Keyword:}

Filler

Cement

Iron Sand

Marshall Test

AC-WC

\begin{abstract}
Asphalt concrete (AC) layer is a road pavement layer consisting of a mixture of binder and aggregate which has gradations continuously, spread, and compacted at a certain temperature. Aphalt concrete wearing course (ACWC) mixture is a type of AC with the functions as a wear layer and withstand stress due to traffic loads. The AC-WC mixture in the upper layer of the AC must be waterproof, durable, flat surface and able to provide good friction with the wheels of the vehicle. On the other hand, climate change and higher vehicle traffic loads will have an impact on the performance of the AC-WC mixture. The use of alternative fillers in AC-WC has an important role in improving the performance of the AC-WC mixture. Iron sand and cement have a rough and hard texture compared to stone ash which is expected to improve the performance of the AC-WC mixture. Therefore, in this research iron sand and cement will be used as an alternative filler in ACWC mixture. Marshall test was conducted to see the performance of the ACWC mixture with a combination of $100 \%$ iron sand filler, $50 \%$ iron sand $+50 \%$ cement, and $100 \%$ cement in a dry and wet conditions. The test results show that iron sand can be used as a filler in AC-WC mixture. The highest stability was obtained in a AC-WC mixture with a cement filler and

the lowest stability from the filler $50 \%$ iron sand $+50 \%$ cement.
\end{abstract}

\section{Korespondensi Penulis:}

Hery Awan Susanto 
Jurusan Teknik Sipil

Universitas Jenderal Soedirman

JL. Raya Mayjen Sungkono Km.5 Blater Purbalingga

Email: hery.susanto@unsoed.ac.id

\section{PENDAHULUAN}

Pembangunan jalan selain memperhatikan aspek kekuatan juga mempertimbangkan aspek ekonomis. Kedua aspek tersebut dapat tercapai jika jalan yang dibangun mampu melayani beban lalu lintas sampai dengan akhir masa pelayanan jalan, menggunakan material yang kuat, dan metode pelaksanaan yang tepat. Penggunaan material yang kuat menjadi faktor utama dalam merencanakan struktur jalan yang sesuai dengan umur pelayanan. Salah satu material penyusun campuran beraspal yang berkontribusi dalam memberikan kekuatan struktur jalan adalah agregat. Agregat alami berupa batu pecah dan filler abu batu adalah material standar dalam campuran beraspal [1].

Campuran asphalt concrete wearing course (AC-WC) adalah campuran hot mix aspal yang terletak paling atas yang berfungsi sebagai lapisan yang menahan beban lalu lintas secara langsung dan sebagai lapis aus yang melindungi lapisan dibawahnya. Campuran AC-WC standar yang didesain saat ini menggunakan agregat batu pecah alami dan filler abu batu. Selain potensi agregat batu pecah yang terus menurun dan terkadang jauh dari lokasi pembangunan jalan yang mengakibatkan biaya pembangunan jalan menjadi mahal. Disisi yang lain beban lalu lintas yang tidak terkendali dan faktor cuaca yang ekstrim saat ini dapat mempercepat kerusakan jalan dan memperpendek umur pelayanan jalan. Oleh karena itu perlu dicari agregat alternatif yang memiliki kekuatan tinggi dalam campuran AC-WC.

Beberapa penelitian terkait dengan penggunaan agregat alternatif telah dilakukan dengan menggunakan pengujian Marshall dan Wheel Tracking. Penelitian agregat alternatif seperti pasir besi, pasir pantai, dan pasir kuarsa sebagai agregat halus dengan pengujian Marshall menunjukkan hasil yang memenuhi standar Bina Marga [2, 3, 4]. Pasir besi dapat digunakan sebagai agregat halus dalam campuran lapisan aus aspal beton. Namun demikian pasir besi sebagai agregat halus menghasilkan lebih banyak rongga dalam campuran dan rongga antar agregat [2]. Penggunaan kadar 0-50\% pasir pantai Carita sebagai agregat halus dalam campuran aspal beton juga telah dilakukan oleh peneliti lain dengan hasil menunjukkan bahwa dengan komposisi tersebut dapat memenuhi standar Bina Marga [3]. Pengaruh penggunaan pasir kuarsa sebagai agregat halus dalam laston AC-WC menunjukkan adanya efek rendaman terhadap penurunan nilai stabilitas [4].

Penelitian yang berkaitan dengan pengunaan agregat alternatif dalam bentuk filler pengganti terhadap kinerja campuran aspal dengan pengujian Marshall diantaranya menggunakan filler debu tanah, semen, kapur, lanau, grajen, gambut, abu ampas tebu, abu vulkanik, dan abu terbang [5, 6, 7, 8, 9, 10, 11, 12]. Dalam penelitian penggunaan filler debu tanah pada campuran Hot Rolled Asphalt (HRA) menunjukkan bahwa nilai stabilitas sebesar 10,75 kN dengan kadar aspal yang cukup tinggi, sehingga secara ekonomis perlu dipertimbangan kembali [5]. Penelitian lain menunjukkan bahwa filler abu ampas tebu juga memenuhi syarat sebagai filler jika digunakan dalam campuran aspal beton [6]. Selanjutnya, penelitian lain mengevaluasi penggunaan filler abu vulkanik terhadap stabilitas campuran aspal beton. Dari hasil penelitian tersebut menghasilkan kesimpulan bahwa abu vulkanik dapat digunakan sebagai filler campuran aspal beton dengan nilai stabilitas sebesar 1000,99 $\mathrm{Kg}$ dan flow 3,13 $\mathrm{mm}$ [7]. Abu terbang batu bara juga dapat dijadikan sebagai mineral filler karena ukuran partikelnya yang sangat halus dan mengandung unsur pozzolan, sehingga dapat berfungsi sebagai bahan pengisi rongga dan pengikat aspal beton [8].

Sementara itu, penelitian tentang variasi jenis dan kadar filler terhadap kinerja campuran Hot Rolled Sheet (HRS) kelas B menggunakan filler semen, kapur, dan lanau menunjukkan bahwa campuran HRS kelas B dengan filler semen lebih stabil, fleksibel, dan awet dibandingkan dengan filler kapur dan lanau [9]. Penelitian yang lain adalah perbandingan filler abu sisa penggergajian kayu/grajen dan filler abu batu terhadap kinerja HRA. Komposisi masing-masing filler yang digunakan dalam campuran tersebut adalah: $100 \%$ abu batu, $50 \%$ abu batu $+50 \%$ abu grajen, dan $100 \%$ abu grajen. Hasil pengujian Marshall menunjukkan bahwa bertambahnya kandungan abu grajen dalam campuran akan menambah kadar aspal $6,9 \%$ pada campuran $100 \%$ abu grajen. Stabilitas dan kelelehan terbaik masih ditunjukkan oleh campuran dengan filler $100 \%$ abu batu, yaitu masing- masing sebesar $1150 \mathrm{Kg}$ dan 4,97 mm [10]. Perbandingan kinerja campuran Marshall dengan menggunakan filler gambut dan filler semen juga sudah dilakukan oleh peneliti lain yang menghasilkan kesimpulan bahwa filler gambut memiliki stabilitas yang lebih rendah dibandingkan filler semen. Walaupun demikian filler gambut masih memenuhi standar Bina Marga [11]. Penelitian tentang perbandingan filler semen dan batu kapur juga telah dilakukan dan hasilnya menunjukkan bahwa filler semen memiliki karakterisitik Marshall yang lebih baik dibandingkan filler batu kapur [12]. 
Beberapa peneliti lain menggunakan kombinasi pengujian Marshall dan Wheel Tracking untuk mengevaluasi kinerja campuran beraspal dengan filler pengganti $[13,14]$. Pemanfaatan filler abu sawit, kapur dan semen dalam campuran HRA telah dilakukan dengan komposisi semen/abu sawit dan kapur/abu sawit masing-masing sebesar: 100/0, 75/25, 50/50, 25/75 dan 0/100. Hasil pengujian Marshall menunjukkan bahwa kadar aspal optimum tertinggi adalah pada campuran filler $100 \%$ abu sawit yaitu sebesar $8,37 \%$ dengan nilai stabilitas Marshall sebesar $1290 \mathrm{Kg}$ dan nilai kelelehan 4,30 mm. Hasil dari pengujian Wheel Tracking menunjukkan bahwa campuran dengan filler $100 \%$ abu sawit memberikan nilai stabilitas dinamis tertinggi (12992,13 lintasan/mm) dengan laju deformasi 0,0034 mm/menit [13]. Sementara itu, perbandingan antara filler bubuk serbuk batu bata dengan filler abu batu dalam campuran HRA juga dilakukan dengan komposisi perbandingan serbuk batu bata dan abu batu divariasikan sebesar: 100/0, 80/20, 60/40, 40/60, 20/80, 0/100. Dari hasil pengujian Marshall menunjukkan bahwa nilai stabilitas tertinggi didapatkan pada kadar campuran $0 \%$ serbuk batu bata-100\% abu batu, yaitu sebesar 13,44 $\mathrm{kN}$ dengan nilai kelelehan sebesar 2,60 mm. Sedangkan pada pengujian Wheel Tracking lendutan permanen terjadi pada kandungan $100 \%$ batu bata- $0 \%$ abu batu [14].

Dalam penelitian tersebut diatas telah banyak yang memanfaatkan beberapa alternatif filler dari material selain abu batu. Beberapa penelitian membandingkan kinerja campuran beraspal dengan variasi jenis filler. Namun demikian penelitian yang menggunakan filler pasir besi dan semen secara bersamaan belum pernah dilakukan. Dalam penelitian terdahulu juga hanya menggunakan campuran jenis HRA dan HRS. Sebagian penelitian menggunakan pasir besi sebagai agregat halus. Belum ada yang menggunakan pasir besi sebagai filler. Penggunaan filler pasir besi di daerah pesisir pantai dengan potensi yang melimpah diharapkan bisa menekan biaya pembangunan jalan. Oleh karena itu perlu dilakukan penelitian untuk mengetahui kinerja campuran AC-WC dengan menggunakan filler pasir besi dan semen sebagai bahan filler alternatif.

Tujuan dari penelitian ini adalah untuk mengetahui pengaruh filler pasir besi dan semen terhadap kinerja campuran AC-WC dengan menggunakan pengujian Marshall. Hasil penelitian ini diharapkan dapat memberikan kontribusi dan rekomendasi tentang penggunaan filler pasir besi dan semen sebagai bahan alternatif dalam campuran AC-WC.

\section{MATERIAL DAN METODOLOGI RISET}

\subsection{Material}

Campuran AC-WC terdiri dari aspal dan agregat. Material aspal dan material agregat diperoleh dari PT. Sambas Wijaya, Purbalingga. Untuk filler semen diperoleh dari toko bangunan di Kabupaten Purbalingga, sedangkan filler pasir besi diperoleh dari penambangan di Kecamatan Adipala, Kabupaten Cilacap. Pengujian aspal dan agregat menggunakan spesifikasi umum campuran aspal panas Bina Marga tahun 2010 [15]. Hasil dari pengujian diperoleh bahwa aspal penetrasi yang akan dipakai dalam pengujian telah memenuhi standar Bina Marga 2010 (Tabel 1). Demikian pula untuk pengujian material agregat kasar, halus, dan filler telah memenuhi standar Bina Marga 2010 (Tabel 2-Tabel 4).

Tabel 1. Hasil pengujian aspal penetrasi 60/70

\begin{tabular}{|c|c|c|c|}
\hline Pengujian & Standar Pengujian & Nilai & Hasil Pengujian \\
\hline Penetrasi pada $25^{\circ} \mathrm{C}(\mathrm{dmm})$ & SNI 06-2456-1991 & $60-70$ & 66 \\
\hline Titik Lembek $\left({ }^{\circ} \mathrm{C}\right)$ & SNI 06-2434-1991 & Min. 48 & $56,70^{\circ} \mathrm{C}$ \\
\hline Titik Nyala $\left({ }^{\circ} \mathrm{C}\right)$ & SNI 06-2433-1991 & Min. 232 & $322^{\circ} \mathrm{C}$ \\
\hline Daktilitas pada $25^{\circ} \mathrm{C}$ & SNI 06-2432-1991 & Min. 100 & $>110 \mathrm{~cm}$ \\
\hline Berat Jenis & SNI 06-2441-1991 & Min. 1 & $1,04 \mathrm{Gr} / \mathrm{cc}$ \\
\hline Indeks penetrasi & - & Min. -1 & 1,19 \\
\hline Kelarutan dalam Toluene (\%) & ASTMD5546 & Min. 99 & $99,30 \%$ \\
\hline \multicolumn{4}{|c|}{ Pengujian residu hasil TFOT } \\
\hline Berat yang hilang (TFOT), $\%$ berat & SNI 06-2440-1991 & Max. 0,80 & $0,28 \%$ \\
\hline Penetrasi pada $25^{\circ} \mathrm{C}(\mathrm{dmm})$ & SNI 06-2456-1991 & Min. 54 & 65,80 \\
\hline Daktilitas pada $25^{\circ} \mathrm{C}(\mathrm{cm})$ & SNI 06-2432-1991 & Min. 100 & $>110 \mathrm{~cm}$ \\
\hline Indeks penetrasi & - & Min. -1 & 1,17 \\
\hline
\end{tabular}

Tabel 2. Hasil pengujian agregat kasar

\begin{tabular}{|c|c|c|c|c|}
\hline \multicolumn{2}{|c|}{ Pengujian } & Standar & Spesifikasi & Hasil Pengujian \\
\hline \multicolumn{2}{|c|}{$\begin{array}{l}\text { Kekekalan bentuk agregat terhadap larutan } \\
\text { natrium dan magnesium sulfat }\end{array}$} & SNI 3407:2008 & Maks. $12 \%$ & $3,13 \%$ \\
\hline $\begin{array}{l}\text { Abrasi dengan mesin } \\
\text { Los Angeles }\end{array}$ & $\begin{array}{l}\text { Campuran AC } \\
\text { bergradasi kasar }\end{array}$ & SNI 2417:2008 & Maks. $30 \%$ & $29,80 \%$ \\
\hline \multicolumn{2}{|c|}{ Kelekatan agregat terhadap aspal } & SNI 03-2439-1991 & Min. 95\% & $98,00 \%$ \\
\hline \multicolumn{2}{|c|}{ Angularitas (kedalaman dari permukaan $<10 \mathrm{~cm}$ ) } & DoT's PTM No. 621 & $95 / 90$ & $94,70 \%$ \\
\hline \multicolumn{2}{|c|}{ Partikel pipih dan lojong } & ASTM D4791 & Maks. $10 \%$ & $8,46 \%$ \\
\hline
\end{tabular}

Pengaruh Penggunaan Filler Pasir Besi dan Semen Dalam Campuran Asphalt Concrete Wearing Course (AC-WC) (Hery Awan Susanto) 


\begin{tabular}{|c|c|c|c|}
\hline Material lolos ayakan No.200 & SNI 03-4142-1996 & Maks. $1 \%$ & $0,67 \%$ \\
\hline \multicolumn{4}{|c|}{ Tabel 3. Hasil pengujian agregat halus } \\
\hline Pengujian & Standar Pengujian & Spesifikasi & Hasil Pengujian \\
\hline Nilai setara pasir & SNI 03-4428-1997 & $\begin{array}{c}\text { Min. } 70 \% \text { AC } \\
\text { bergradasi kasar }\end{array}$ & $70,85 \%$ \\
\hline Material lolos ayakan No.200 & SNI 03-4428-1997 & Maks. $8 \%$ & $6,67 \%$ \\
\hline Angularitas (kedalaman dari permukaan $<10 \mathrm{~cm}$ ) & $\begin{array}{c}\text { AASTHO TP-33 atau } \\
\text { ASTM C1252-93 }\end{array}$ & Min. 45 & $93,32 \%$ \\
\hline Kadar lempung & SNI $3423: 2008$ & $1 \%$ & $0,98 \%$ \\
\hline
\end{tabular}

Tabel 4. Hasil pengujian filler pasir besi dan semen

\begin{tabular}{lccc}
\hline \multicolumn{1}{c}{ Pengujian } & Standar Pengujian & Spesifikasi & Hasil Pengujian \\
\hline $\begin{array}{l}\text { Berat butiran yang lolos ayakan 75 mikron } \\
\text { pasir besi }\end{array}$ & SNI.03-4142-1996 & Min. 75\% & $83,40 \%$ \\
\hline $\begin{array}{l}\text { Berat butiran yang lolos ayakan 75 mikron } \\
\text { semen }\end{array}$ & SNI.03-4142-1996 & Min. 75\% & $82,28 \%$ \\
\hline
\end{tabular}

Gambar 1 menunjukkan hasil pengujian sieve analisis gradasi agregat campuran yang berada dalam rentang batas maksimum dan minimum gradasi sesuai dengan standar Bina Marga 2010 untuk campuran ACWC. Sementara itu Tabel 5 menjelasksn hasil pengujian berat jenis untuk masing-masing filler yang digunakan dalam campuran AC-WC. Hasil pengujian berat jenis masing-masing filler akan digunakan untuk menghitung karakteristik volumetrik sampel Marshall.

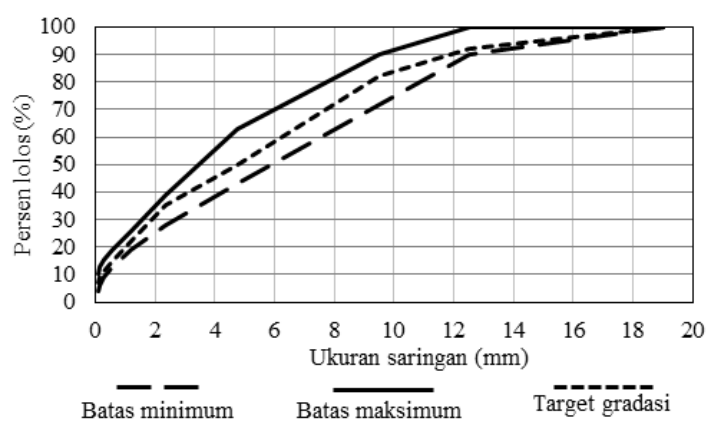

Gambar 1. Gradasi agregat campuran

Tabel 5.Hasil perhitungan Berat Jenis

\begin{tabular}{lccc}
\hline \multicolumn{1}{c}{ Prosentase Filler } & BJ Bulk & BJ Apparent & BJ Efektif \\
\hline $100 \%$ Pasir Besi & 2,83 & 3,01 & 2,92 \\
\hline $100 \%$ Semen & 2,82 & 2,95 & 2,89 \\
\hline $50 \%$ Pasir Besi+50\% Semen & 2,83 & 2,99 & 2,91 \\
\hline
\end{tabular}

\subsection{Metodologi Riset}

Penelitian ini dilakukan dengan pengujian laboratorium di laboratorium transportasi Jurusan Teknik Sipil Universitas Jenderal Soedirman. Penelitian ini bertujuan untuk mengetahui tentang pengaruh filler pada campuran laston lapis aus atau asphalt concreate wearing course (AC-WC).

Pengujian yang dilakukan adalah pengujian Marshall untuk beban lalu lintas tinggi. Pengujian dimulai dari pengujian material penyusun campuran AC-WC. Setelah itu dilakukan pengujian Marshall dalam kondisi sampel kering (dry) dan rendaman (wet) untuk mendapatkan nilai kadar aspal optimum (Pb.opt), nilai-nilai karakteristik Marshall (stabilitas, flow, dan Marshall Quotient (MQ)), dan nilai-nilai karakteristik volumetrik Marshall (Void In the Mix (VIM), Void Filled with Bitumen (VFB), Void Mix Aggregate (VMA)). Selanjutnya hasil dari pengujian Marshall dilakukan analisis untuk mendapatkan kesimpulan dari penelitian ini. 


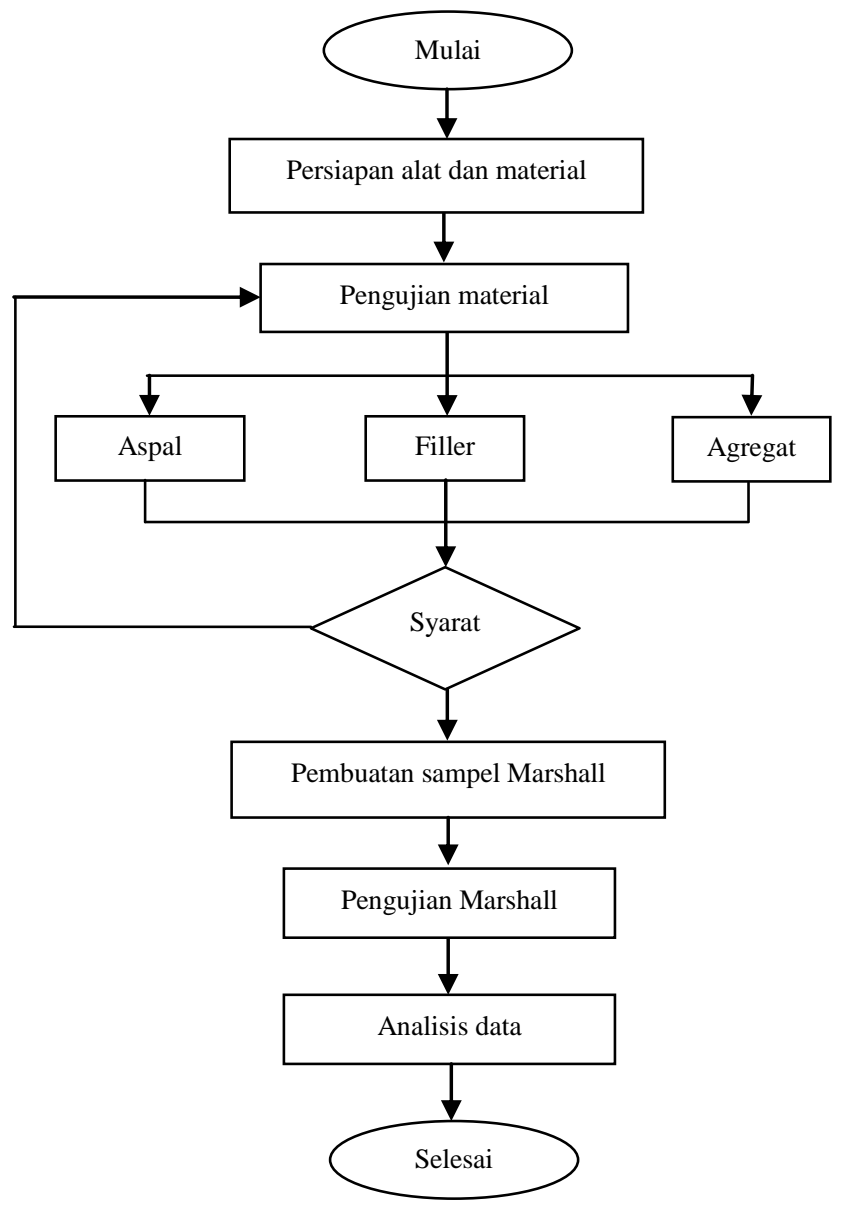

Gambar 2. Diagram alir penelitian

Tabel 6-Tabel 7 menunjukkan perkiraan benda uji yang dibuat dalam penelitian ini. Penyiapan sampel dilakukan dua tahap, yaitu tahap 1 untuk menentukan Pb.opt dengan filler abu batu (standar) dan tahap 2 pengujian Marshall dengan komposisi filler pengganti.

Tabel 6. Tahap 1 Uji Marshall standar (2x75) untuk menentukan kadar aspal optimum

\begin{tabular}{ccccccc}
\hline \multirow{2}{*}{ Jenis Filler } & \multicolumn{7}{c}{ Variasi Kadar Aspal } & \multirow{2}{*}{ Sub Total } \\
\cline { 2 - 6 } & $-1 \%$ & $-0,50 \%$ & $\mathrm{~Pb}$ & $0,5 \%$ & $1 \%$ & \\
\hline Abu Batu & $2 \mathrm{D}$ & $2 \mathrm{D}$ & $2 \mathrm{D}$ & $2 \mathrm{D}$ & $2 \mathrm{D}$ & $10 \mathrm{D}$ \\
\hline Abu Batu & $2 \mathrm{~W}$ & $2 \mathrm{~W}$ & $2 \mathrm{~W}$ & $2 \mathrm{~W}$ & $2 \mathrm{~W}$ & $10 \mathrm{~W}$ \\
\hline \multicolumn{7}{c}{ Total } \\
\hline D: dry and W:wet
\end{tabular}

Tabel 7. Tahap 2 Uji Marshall standar (2x75) pada kadar aspal optimum

\begin{tabular}{|c|c|c|c|c|c|c|}
\hline \multirow{2}{*}{ Jenis Filler } & \multicolumn{5}{|c|}{ Variasi Kadar Aspal } & \multirow{2}{*}{ Sub Total } \\
\hline & $-1 \%$ & $-0,50 \%$ & Pb.opt & $0,5 \%$ & $1 \%$ & \\
\hline \multirow{2}{*}{ Pasir Besi $100 \%$} & $2 \mathrm{D}$ & $2 \mathrm{D}$ & $2 \mathrm{D}$ & $2 \mathrm{D}$ & $2 \mathrm{D}$ & $10 \mathrm{D}$ \\
\hline & $2 \mathrm{~W}$ & $2 \mathrm{~W}$ & $2 \mathrm{~W}$ & $2 \mathrm{~W}$ & $2 \mathrm{~W}$ & $10 \mathrm{~W}$ \\
\hline \multirow{2}{*}{ Semen $100 \%$} & $2 \mathrm{D}$ & $2 \mathrm{D}$ & $2 \mathrm{D}$ & $2 \mathrm{D}$ & $2 \mathrm{D}$ & 10D \\
\hline & $2 \mathrm{~W}$ & $2 \mathrm{~W}$ & $2 \mathrm{~W}$ & $2 \mathrm{~W}$ & $2 \mathrm{~W}$ & $10 \mathrm{~W}$ \\
\hline \multirow{2}{*}{$50 \%$ Pasir Besi+50\% Semen } & $2 \mathrm{D}$ & $2 \mathrm{D}$ & $2 \mathrm{D}$ & $2 \mathrm{D}$ & $2 \mathrm{D}$ & 10D \\
\hline & $2 \mathrm{~W}$ & $2 \mathrm{~W}$ & $2 \mathrm{~W}$ & $2 \mathrm{~W}$ & $2 \mathrm{~W}$ & $10 \mathrm{~W}$ \\
\hline \multicolumn{6}{|c|}{ Total } & 60 \\
\hline
\end{tabular}

Penentuan $\mathrm{Pb}$.opt awal dilakukan dengan menggunakan rumus empiris dari Bina Marga sebagai berikut ini. $\mathrm{Pb}=0,035(\% \mathrm{CA})+0,045(\% \mathrm{FA})+0,18(\% \mathrm{FF})+\mathrm{K}$

dimana :

$\mathrm{Pb}=$ Perkiraan kadar aspal terhadap campuran; prosentase berat terhadap campuran (\%).

Pengaruh Penggunaan Filler Pasir Besi dan Semen Dalam Campuran Asphalt Concrete Wearing Course 
$\mathrm{CA}=$ Coarse Agregate; Agregat kasar tertahan saringan No.8 (2,36 mm).

$\mathrm{FA}=$ Fine Agregate Agregat halus lolos saringan No.8 (2,36 mm).

$\mathrm{FF}=$ Fine Filler; Bahan pengisi lolos saringan No.200 (0,075 mm).

$\mathrm{K}=$ Konstansta; untuk laston AC-WC dipakai 0,5-1,0.

Bila kadar aspal perkiraan Pb.opt telah diketahui, misalnya 5,3\%, maka dibulatkan sampai 0,5\% terdekat menjadi 5,5\%. Berdasarkan perkiraan kadar aspal $\mathrm{Pb}$.opt, dibuat benda uji dengan variasi kadar aspal. Kadar aspal yang perlu dibuat adalah $-1 \% ;-0,5 \% ; \mathrm{Pb} ;+0,5 \% ;+1 \%$. Dari hasil pengujian tersebut, kemudian diplotkan pada suatu grafik hubungan antara kadar aspal dengan semua parameter Marshall. Kemudian tentukan kadar aspal optimum (Pb.opt). Kadar aspal optimum ini digunakan sebagai patokan kadar aspal untuk melangkah pada pengujian tahap lanjutan.

\section{HASIL DAN PEMBAHASAN}

Hasil pengujian dari penelitian ini meliputi hasil pengujian $\mathrm{Pb} . o p t$, pengujian karakteristik Marshall (dry), dan pengujian karakteristik Marshall rendaman (wet).

\subsection{Penentuan Kadar Aspal Optimum}

Pendekatan untuk memperoleh nilai Pb.opt pembulatan dari persamaan (1) adalah sebesar 4,5\%. Setelah nilai pendekatan Pb.opt diperoleh, maka nilai tersebut dijadikan sebagai nilai tengah kadar aspal yang akan digunakan pada campuran aspal tahap kesatu. Adapun kadar aspal yang digunakan adalah sebagai berikut: $3,5 \% ; 4 \% ; 4.5 \% ; 5 \% ; 5,5 \%$.

Tabel 8 menunjukkan nilai karakteristik Marshall untuk mencari nilai Pb.opt.

Tabel 8. Nilai rata-rata karakteristik Marshall untuk mencari Pb.opt

\begin{tabular}{cccccccc}
\hline $\begin{array}{c}\text { Kadar aspal } \\
(\%)\end{array}$ & $\begin{array}{c}\text { Density } \\
(\mathrm{Gr} / \mathrm{cc})\end{array}$ & $\begin{array}{c}\text { VMA } \\
(\%)\end{array}$ & $\begin{array}{c}\text { VIM } \\
(\%)\end{array}$ & $\begin{array}{c}\text { VFB } \\
(\%)\end{array}$ & $\begin{array}{c}\text { Stabilitas } \\
(\mathrm{Kg})\end{array}$ & $\begin{array}{c}\text { Flow } \\
(\mathrm{mm})\end{array}$ & $\begin{array}{c}\text { MQ } \\
(\mathrm{Kg} / \mathrm{mm})\end{array}$ \\
\hline 3,5 & 2,40 & 12,30 & 4,21 & 65,74 & 826,15 & 6,30 & 132,64 \\
\hline 4,0 & 2,35 & 14,99 & 5,99 & 60,08 & 947,10 & 6,83 & 142,94 \\
\hline 4,5 & 2,37 & 14,78 & 4,57 & 69,08 & 955,77 & 5,99 & 159,23 \\
\hline 5,0 & 2,38 & 14,84 & 3,44 & 76,85 & 1165,74 & 5,45 & 213,21 \\
\hline 5,5 & 2,38 & 15,01 & 2,43 & 83,82 & 967,95 & 4,91 & 209,55 \\
\hline
\end{tabular}

Dari hasil tersebut di atas, maka diperoleh kadar aspal optimum (Pb.opt) adalah 5,5\%. Tabel 9 menggambarkan hubungan kadar aspal dengan tujuh sifat campuran aspal untuk mencari $\mathrm{Pb}$.opt.

Tabel 9. Penentuan kadar aspal optimum (Pb.opt)

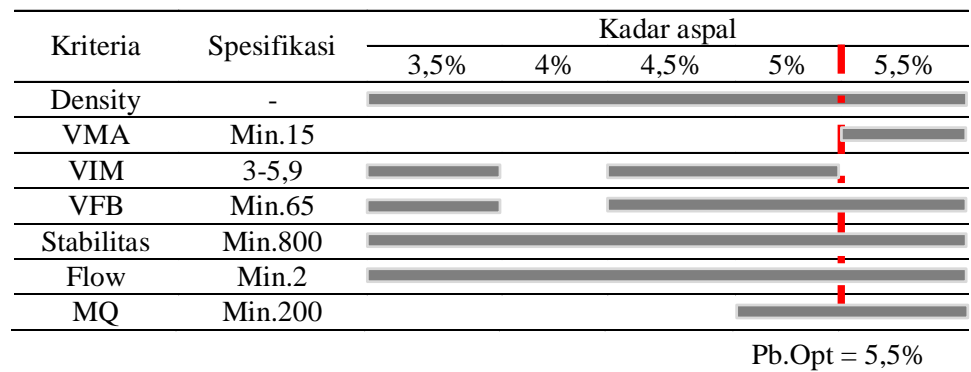

\subsection{Pengujian Karakteristik Marshall}

Pengujian keadaan kering adalah pengujian Marshall yang sesuai dengan peraturan Bina Marga yang berlaku dimana sampel diuji sesuai dengan prosedur pengujian Marshall. Untuk filler 100\% pasir besi, dengan kadar aspal 5,5\% nilai stabilitas sebesar 1396,70 Kg, nilai flow sebesar 3,25 mm, dan MQ sebesar $431,10 \mathrm{Kg} / \mathrm{mm}$. Untuk filler $100 \%$ semen, dengan kadar aspal 5,5\% nilai stabilitas sebesar $1562,86 \mathrm{Kg}$, nilai flow sebesar 4,35 mm, dan MQ sebesar 376,27 Kg/mm. Sedangkan untuk filler 50\% pasir besi+50\% semen, dengan kadar aspal 5,5\% nilai stabilitas sebesar 1433,71 Kg, nilai flow sebesar 4,65 mm, dan MQ sebesar $307,27 \mathrm{Kg} / \mathrm{mm}$. Dari hasil pengujian tersebut dapat diketahui bahwa nilai stabilitas tertinggi diperoleh dari filler semen. Hasil ini menunjukkan bahwa filler semen memiliki kekuatan yang lebih tinggi dibandingkan dengan pasir besi. Walaupun demikian filler pasir besi memenuhi standar minimum dari stabilitas yang ditentukan dalam Bina Marga. Sedangkan 50\% filler pasir besi+50\% semen memiliki stabilitas yang paling kecil. Sementara itu dari pengujian karakteristik volumetrik Marshall dapat diketahui bahwa nilai VFB dan VIM tidak memenuhi syarat minimum standar Bina Marga. Hal ini dikarenakan berat jenis efektif dari variasi filler $100 \%$ pasir besi $(2,92)$, $50 \%$ pasir besi $+50 \%$ semen $(2,91)$, dan $100 \%$ semen $(2,89)$ yang telalu besar 
sehingga menyebabkan nilai VMA besar yang berpengaruh kepada nilai VFB menjadi kecil dan nilai VIM menjadi besar.

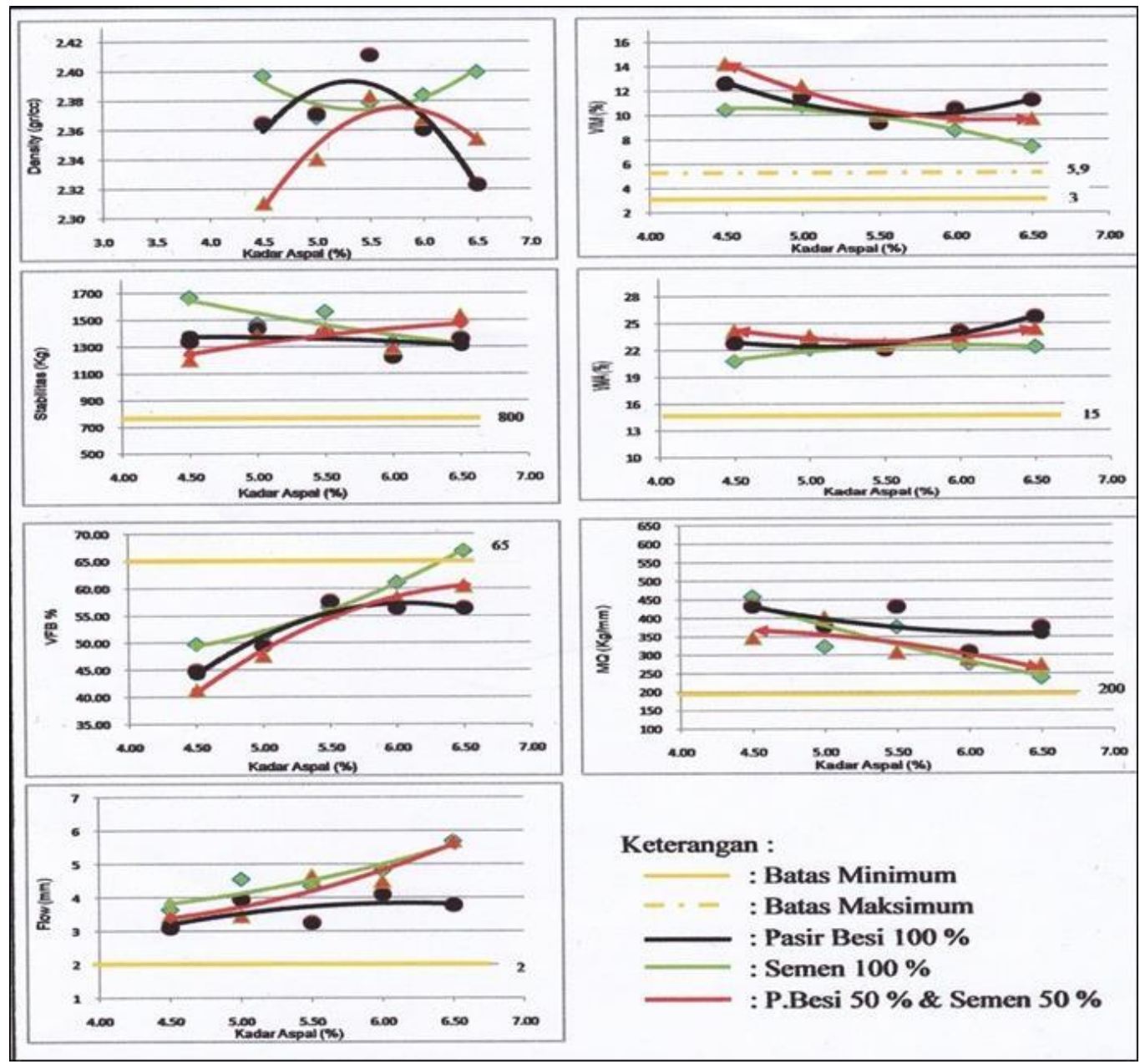

Gambar 3. Karakteristik Marshall kondisi sampel kering (dry)

\subsection{Pengujian Karakteristik Marshall Rendaman}

Pengujian keadaan rendaman adalah pengujian Marshall dengan sampel direndam dalam air selama $1 \times 24$ jam pada temperatur $60{ }^{\circ} \mathrm{C}$. Untuk filler $100 \%$ pasir besi, dengan kadar aspal 5,5\% nilai stabilitas sebesar 1655,07 Kg, nilai flow sebesar 6,30 mm, dan MQ sebesar 265,54 Kg/mm. Untuk filler 100\% semen, dengan kadar aspal 5,5\% nilai stabilitas sebesar 2103,55 Kg, nilai flow sebesar 5,95 mm, dan MQ sebesar $353,56 \mathrm{Kg} / \mathrm{mm}$. Sedangkan untuk filler $50 \%$ pasir besi+50\% semen, dengan kadar aspal 5,5\% nilai stabilitas sebesar $1616,52 \mathrm{Kg}$, nilai flow sebesar $6,05 \mathrm{~mm}$, dan MQ sebesar 267,33 Kg/mm. Hasil pengujian ini menunjukkan bahwa stabilitas filler semen masih lebih tinggi dibandingkan filler pasir besi. Namun demikian stabilitas filler pasir besi telah memenuhi standar Bina Marga. Sedangkan nilai stabilitas terkecil diperoleh dari $50 \%$ filler pasir besi $+50 \%$ semen. Sementara itu dari pengujian karakteristik volumetrik Marshall dapat diketahui bahwa nilai VFB dan VIM tidak memenuhi syarat minimum standar Bina Marga. Hal ini dikarenakan berat jenis efektif dari variasi filler $100 \%$ pasir besi $(2,92), 50 \%$ pasir besi+50\% semen $(2,91)$, dan $100 \%$ semen $(2,89)$ yang telalu besar, sehingga menyebabkan nilai VMA besar yang berpengaruh kepada nilai VFB menjadi kecil dan nilai VIM menjadi besar. 

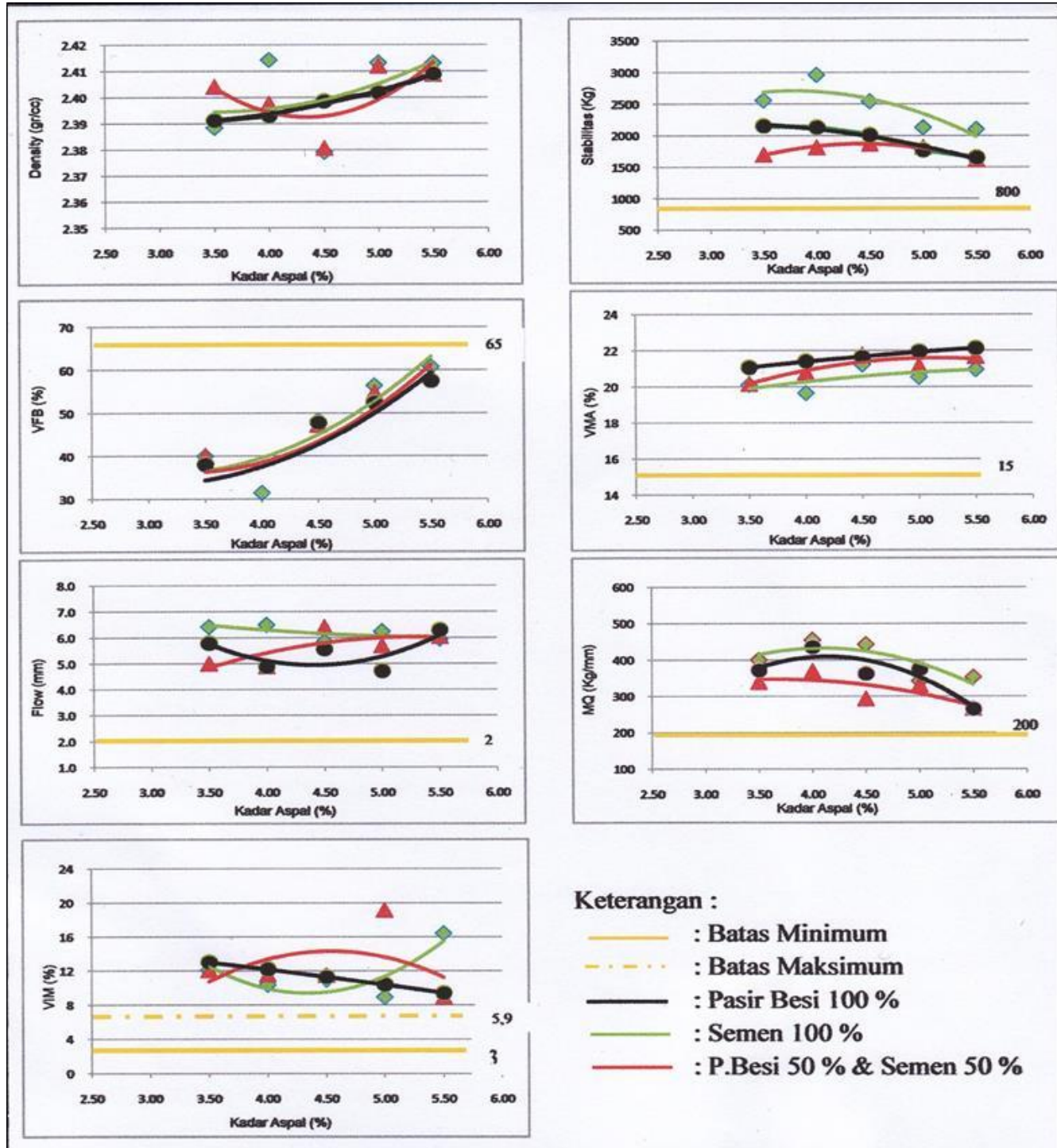

\section{Keterangan :}

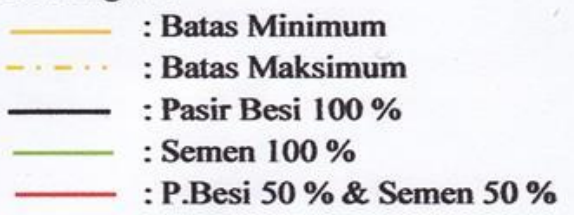

Gambar 4. Karakteristik Marshall kondisi sampel rendaman (wet)

\section{KESIMPULAN}

Penelitian ini dilakukan untuk mengetahui potensi kinerja campuran AC-WC dengan beberapa komposisi filler alternatif, yaitu $100 \%$ pasir besi, $100 \%$ semen, dan $50 \%$ pasir besi+50\% semen. Hasil pengujian terhadap karakteristik Marshall test dalam kondisi sampel kering dan sampel rendaman adalah sebagai berikut ini.

a) Pasir besi dapat dijadikan sebagai filler pada campuran laston lapis aus (AC-WC) dengan nilai stabilitas yang cukup tinggi.

b) Dari hasil pengujian karakteristik Marshall dapat diketahui bahwa nilai stabilitas filler pasir besi 1396,7 $\mathrm{Kg}$, flow 3,25 mm, dan MQ 431,1 Kg/mm. Nilai stabilitas tertinggi diperoleh dari filler semen dan terendah dari filler $50 \%$ pasir besi+50\% semen.

c) Pengaruh sampel Marshall rendaman akan meningkatkan nilai stabilitas dan flow untuk berbagai komposisi jenis filler yang digunakan.

d) Karakteristik volumetrik sampel Marshall dari ketiga jenis filler tersebut memiliki nilai yang hampir sama baik untuk VFB, VMA, dan VIM.

\section{DAFTAR PUSTAKA}

[1] S. Sukirman, "Perkerasan Lentur Jalan Raya, Penerbit Nova, Bandung," 1999.

[2] S.H. Aly, et al., "Penggunaan Pasir Besi Sebagai Agregat Halus Pada Beton Aspal Lapisan Aus," Jurnal Transportasi, Vo.11 No.2: 123-134, FT Universitas Hasanuddin, Makassar, 2011. 
[3] I. Arifiardi, et al., "Pengaruh Penggunaan Pasir Pantai Carita sebagai Campuran Agregat Halus pada Lapis Permukaan Aspal Beton terhadap Persyaratan Parameter Marshall," Jurnal Menara Jurusan Teknik Sipil FT. UNJ, Volume XI-No.1, Jakarta, Januari 2016.

[4] G.B. Ramadhan dan L.B. Suparma, "Pengaruh Penggunaan Pasir Kuarsa pada Laston AC-WC sebagai Pengganti Agregat Halus," Jurnal HPJI, Vol.4 No.2: 91-104, Juli, Bandung, 2018.

[5] A.H. Wenan, "Pengaruh Jenis Filler pada Sifat Campuran Hot Rolled Asphalt," Tesis Magister, STJR-ITB, Bandung, 1994.

[6] H.M. Syarkawi, "Pemanfaatan Abu Ampas Tebu sebagai Bahan Filler terhadap Karakteristik Campuran Aspal," Majalah Ilmiah Al-Jibra, ISSN 1441-7797, Makasar, 2011.

[7] O. Sihotang dan S. Sinuhaji, "Penggunaan Abu Vulkanik Sinabung Terhadap Stabilitas Campuran Aspal Beton (Hot Mix)," Jurnal Rekayasa Konstruksi Mekanika Sipil, Vo. 1 No.2, ISSN 2614-5707, Agustus 2018.

[8] A. Tahir, "Karakteristik Campuran Beton dengan menggunakan Variasi Kadar Filler Abu Terbang Batu Bara," Jurnal SMARTek, Vol. 7 No. 4 November, Palu, 2009.

[9] A.T. Mulyono, "Pengaruh Jenis dan Kadar Filler terhadap Stabilitas, Fleksibilitas dan Tingkat Durabilitas HRS (Hot Rolled Sheet) Kelas B," Media Teknik, No.3, Edisi November, UGM, Yogyakarta, 1996.

[10] M. Deddy, "Evaluasi Kinerja Campuran Hot Rolled Asphalt (HRA) dengan menggunakan Filler Abu Sisa Penggergajian Kayu," Master Thesis, Universitas Diponegoro, 2003.

[11] L. Sentosa, "Penggunaan Abu Gambut sebagai Filler pada Campuran Lapis Beton dengan Pengujian Marshall," Media Teknik Sipil, Juli, Pekanbaru, 2006.

[12] M.R.T. Dalimunthe dan M. Ardan, "Analisa Karakteristik Campuran Aspal Beton dengan Filler yang Berbeda terhadap Nilai Marshall," Journal of Civil Engineering, Building, and Transportation, 3(1): 19-26, ISSN 2549-6386 (online), Universitas Medan Area, Medan, 2019.

[13] L. Sentosa, "Kinerja Laboratorium Hot Rolled Asphalt dengan Abu Sawit sebagai Filler," Tesis Magister, STJRITB, Bandung, 2001.

[14] Yasruddin, "Kinerja Laboratorium pada Hot Rolled Asphalt dengan Kandungan Batu Bata yang dihaluskan sebagai Filler," Tesis Magister, STJR-ITB, Bandung, 2000.

[15] Anonim, "Spesifikasi Umum Campuran Aspal Panas," Bina Marga, 2010. 
Techno Vol. 21, No. 1, April 2020 : 37-46 